\title{
Isolation from forest reduces pollination, seed predation and insect scavenging in Swiss farmland
}

\author{
Nina Farwig • Debra Bailey • Estée Bochud · John D. Herrmann • \\ Eveline Kindler · Niklaus Reusser · Christof Schüepp · \\ Martin H. Schmidt-Entling
}

Received: 14 November 2008/ Accepted: 4 June 2009/Published online: 16 June 2009

(C) Springer Science+Business Media B.V. 2009

\begin{abstract}
Habitat loss and fragmentation lead to changes in species richness and composition which may affect ecosystem services. Yet, few studies distinguish between the effects of habitat loss and isolation, or how multiple ecosystem services may be affected simultaneously. We investigated the effects of variation in cover of woody and open semi-natural habitats and isolation from forest on the relative functioning of pollination, seed predation and insect scavenging in agricultural landscapes. We established 30 sites in grassland locations in the Swiss plateau around Berne. The sites varied independently in their isolation from forest edges, in the percentage of woody habitats and in the percentage of open seminatural habitats in the surrounding landscape $(500 \mathrm{~m}$ radius). We experimentally exposed primroses,
\end{abstract}

N. Farwig $(\bowtie)$

Department of Ecology, Conservation Ecology, Faculty of Biology, Philipps-Universität Marburg, Karl-von-Frisch-

Str. 8, 35032 Marburg, Germany

e-mail: farwig@staff.uni-marburg.de

N. Farwig - E. Bochud · J. D. Herrmann .

E. Kindler · N. Reusser - C. Schüepp .

M. H. Schmidt-Entling

Institute of Ecology and Evolution (IEE), Community

Ecology, University of Bern, Baltzerstrasse 6, 3012 Bern,

Switzerland

D. Bailey

Agroscope Reckenholz-Tänikon, Research Station ART, Reckenholzstrasse 191, 8046 Zürich, Switzerland sunflower seeds and cricket corpses during spring 2008. None of the three studied services was affected by variation in woody or open semi-natural habitat cover. However, the proportion of flowers setting seed was significantly reduced by isolation from forest. Further, seed predation and insect scavenging were significantly lower at isolated sites than at sites connected to woody habitat. This pattern was particularly pronounced for seeds and insect corpses that were enclosed by wire netting and thus inaccessible to vertebrates. Thus, all three studied services responded quite similarly to the landscape context. The observed small-scale determination of seed set, seed predation and insect scavenging contrasts with larger-scale determination of pollination and insect pest control found in other studies.

Keywords Ecosystem service $\cdot$ Forest . Habitat fragmentation - Habitat loss . Open semi-natural habitat $\cdot$ Swiss plateau

\section{Introduction}

Human-shaped landscapes such as agricultural areas cover $\sim 40 \%$ of the earth's land surface (Foley et al. 2005). In these landscapes most of the natural habitat has been replaced by cropland, and the remaining native habitat is usually highly fragmented (Tivy 1990; Saunders et al. 1991; Robinson and Sutherland 2002). Habitat loss and isolation are among the major 
causes of biodiversity decline (Didham et al. 1996; Chapin et al. 2000; Tilman et al. 2002). Thus, there is increasing concern that low biodiversity in intensively managed agricultural ecosystems may result in modifications or even disruptions of ecological services and functions (Matson et al. 1997; Luck et al. 2003; Tscharntke et al. 2005; Larsen et al. 2005; Kremen et al. 2007). Important ecosystem services in agricultural landscapes include pollination, seed predation, and insect scavenging (Kruess and Tscharntke 1994; Didham et al. 1996; Watts and Didham 2006; Kremen et al. 2007). Insect pollination enhances fruit and seed production in most nongramineous crops (Klein et al. 2007) and seed predation can affect the dynamics of both weeds and crop plants in arable and grassland systems (White et al. 2007). Although insect scavenging is of less direct relevance to agriculture, it may reflect predation pressure on slow-moving pest species. Furthermore, the rate at which insect carcasses are removed from a system can be important for the dynamics of economically important insect pathogens (Tscharntke et al. 2007).

Declining species richness and changes of ecological services in fragmented landscapes are attributed to habitat loss or isolation, but few studies have separated the effects of the two (Fahrig 2003; Diekötter et al. 2007; Haynes et al. 2007). It is generally accepted that habitat loss has negative effects on biodiversity and that the share of habitat in the landscape is positively correlated with species richness (Steffan-Dewenter et al. 2002; Kremen et al. 2004; Billeter et al. 2008). The effects of fragmentation per se on biodiversity are less understood and are as likely to be positive as negative (Fahrig 2003). This is especially the case at the landscape scale where matrix composition may lead to difficulties in separating effects of habitat loss and isolation (Diekötter et al. 2007; Haynes et al. 2007). We therefore distinguished between effects of habitat loss and isolation through a GIS-based selection of study sites that vary independently in the two factors.

Ecosystem services in open agricultural landscapes may depend on woody and/or open semi-natural habitats (e.g. Kremen et al. 2004; Klein et al. 2007; Jauker et al. 2009). Woody habitats are subject to minimal disturbance, and are often closest to the potential natural vegetation, both making them a potential source habitat for ecosystem service providing animals. Furthermore, many open land organisms depend on trees for nesting (e.g. birds, bees; Kremen et al. 2004; Sanderson et al. 2009), for foraging (e.g. Meek et al. 2002), to find shelter from hot or windy weather (e.g. slugs; Griffith et al. 1998), and through their production of leaf litter serving as winter refuge for many terrestrial invertebrates (e.g. Duelli and Obrist 2003). On the other hand, the faunas of open and woody habitat are often highly distinct (e.g. beetles; Fournier and Loreau 2001), suggesting open semi-natural habitats as a source of ecosystem service providing agents in farmland. As it is unlikely that all animals are affected equally (Didham et al. 1996; Kirika et al. 2008; Tylianakis et al. 2008), responses to habitat loss and isolation might differ among ecosystem services (Kotze and Lawes 2007; Farwig et al. 2008).

We therefore studied seed predation, insect scavenging, and pollination in 30 patches of grassland. In line with the potential role of woody habitats, our study was designed to detect effects of the amount of and isolation from woody habitats on ecosystem services in grassland. To account for the potential role of open semi-natural habitats, we considered the percentage of fallows and low-intensity grassland as an alternative measure of landscape-wide habitat cover. At each site we (1) observed the floral visitors and determined the seed set of potted primrose, (2) exposed sunflower seeds to determine the seed predation pressure and (3) exposed cricket corpses to examine the rate of insect scavenging. We hypothesized that there would be more floral visitors, higher seed set, higher seed predation and higher insect scavenging rates in landscapes with high compared to low percentages of woody and/or open semi-natural habitat due to higher population sizes of ecosystem service providing animals. Further, we predicted that isolation from forest would negatively affect pollination, seed predation and insect scavenging because of constraints in the foraging and dispersal movements of the respective organisms.

\section{Methods}

Study region and experimental design

The study took place between March and May 2008 in the Swiss plateau around Berne. The study sites were 
distributed over an area of 23 by $32 \mathrm{~km}$ to the north and west of the city. The altitude varied between 465 and $705 \mathrm{~m}$ above sea level. The study region was characterized by agricultural areas interspersed mostly by forest fragments. The forest was predominately deciduous or mixed, and dominated by native trees such as Fagus sylvatica. The experimental study sites were located on thirty grassland patches that were selected according to their percentage of woody habitat cover in a $500 \mathrm{~m}$ radius and the level of local isolation (Fig. 1). The percentage of woody habitat in a $500 \mathrm{~m}$ radius around the sites varied from $4-74 \%$. Ten of the sites were located at the edge of dense and tall-growing forest to represent no isolation from native habitat (Fig. 1a). Another ten sites were connected to smallsized woody habitats such as hedgerows or single trees (Fig. 1b). The remaining ten sites were isolated from any woody habitat by at least $100 \mathrm{~m}$ distance (Fig. 1c). There was no statistical dependency between the percentage of woody habitat cover and the level of isolation $\left(F_{2,27}=0.004, P>0.99\right)$. Sites with different levels of isolation and with different percentages of woody habitat in the surrounding landscape were spatially interspersed. In addition, percentages of open semi-natural habitat were derived for the studied landscapes from the official record of ecological compensation areas, which was further verified in the field. The percentage of open semi-natural habitats varied from 0 to $11 \%$. It showed some covariation with the percentage of woody habitat $(n=30, t=-1.96$, $P=0.07)$, but not with isolation to forest $\left(F_{2}\right.$, ${ }_{27}=0.42, P=0.52$ ). Open semi-natural habitats were low-intensity permanent grasslands plus fallows sown with wildflowers (Aviron et al. 2009). Woody habitats comprised hedgerows, orchards, tree lines, single-standing trees and forest. Woody habitats were derived from official digital land-use maps (vector25, swisstopo, Wabern) and verified using aerial photographs and field inspection.

The grassland patches had been formerly used as meadow $(n=21)$ or pasture $(n=9)$, respectively. Management type was not significantly correlated to woody habitat cover or the level of local isolation $(P>0.2)$. In the study year, none of the studied grassland patches had been managed prior to our investigations. For pollination investigations, we placed four pots each containing an individual primrose (Primula elatior). We purchased 120 primroses from a local wildflower breeder in Oberbüren (UFA-
Samen). The plants had been raised from seeds derived from at least 50 different parental plants. For investigations of seed predation and insect scavenging, four gauze sheets (two different types) baited with sunflower seeds or cricket corpses were secured $3 \mathrm{~m}$ from each other. The first type was exposed to allow access by all organisms to the sunflower seeds or cricket corpses attached to gauze $(45 \times 30 \mathrm{~cm} ; 0.3 \mathrm{~mm}$ mesh $)$ on the ground. The second type was enclosed by a wire cage $(45 \times 30 \times 7 \mathrm{~cm})$ which excluded organisms larger than $1.2 \times 1.2 \mathrm{~cm}$ (mesh size). We assumed that open gauze sheets can be accessed by both vertebrates and invertebrates, and that enclosed gauze sheets can be accessed by invertebrates only. The difference between the two should thus reflect the action of vertebrates.

Ecological processes-pollination, seed predation, insect scavenging

Primula elatior is a small perennial rosette plant. As it is distylic and self-incompatible, only pollination between pin and thrum flowers results in seed set (Jacquemyn et al. 2001). Primula elatior is a typical forest plant but can occasionally be found in meadows outside forests (Valentine 1948). However, in our study area the species occurred almost exclusively in forest habitats. In April we placed four potted plants with a balanced pin-thrum ratio at each site. Floral visitation was recorded during $20 \mathrm{~min}$ between 1000 and 1600 hours in similar weather conditions. We visited each site for three such observation rounds at different times (12.04.200825.04.2008) and recorded floral visits by all insect species. Further, we recorded the number of open flowers of the primroses as well as the percentage of surrounding flower cover in a $5 \mathrm{~m}$ radius around the pots. Fruit set of primroses was recorded in May. To estimate plant reproductive success, we counted the proportion of flowers setting seed per site.

To measure seed predation, one of each type of gauze sheets was placed at each site. We expected seed predation to be higher in the exposed rather than enclosed gauze sheets (Kotze and Lawes 2007). Each gauze sheet contained ten sunflower seeds that were glued to the gauze with hot-melt adhesive. New seeds were placed on the gauze on a weekly basis and each site was visited three times (19.04.2008-29.04.2008). The number of lost and damaged seeds was recorded. 
Fig. 1 Three of the 30 study sites demonstrating the independent variation in the percentage of woody habitat and local isolation. Site $\mathbf{a}$ is adjacent to forest, with $19.1 \%$ woody habitat in the surrounding landscape. Site $\mathbf{b}$ is connected to singlestanding trees and hedgerows, but has only $3.6 \%$ of woody habitat in the surrounding landscape. Site $\mathbf{c}$ is isolated from woody habitats by $100 \mathrm{~m}$, but has $74.2 \%$ woody habitat in the surrounding landscape
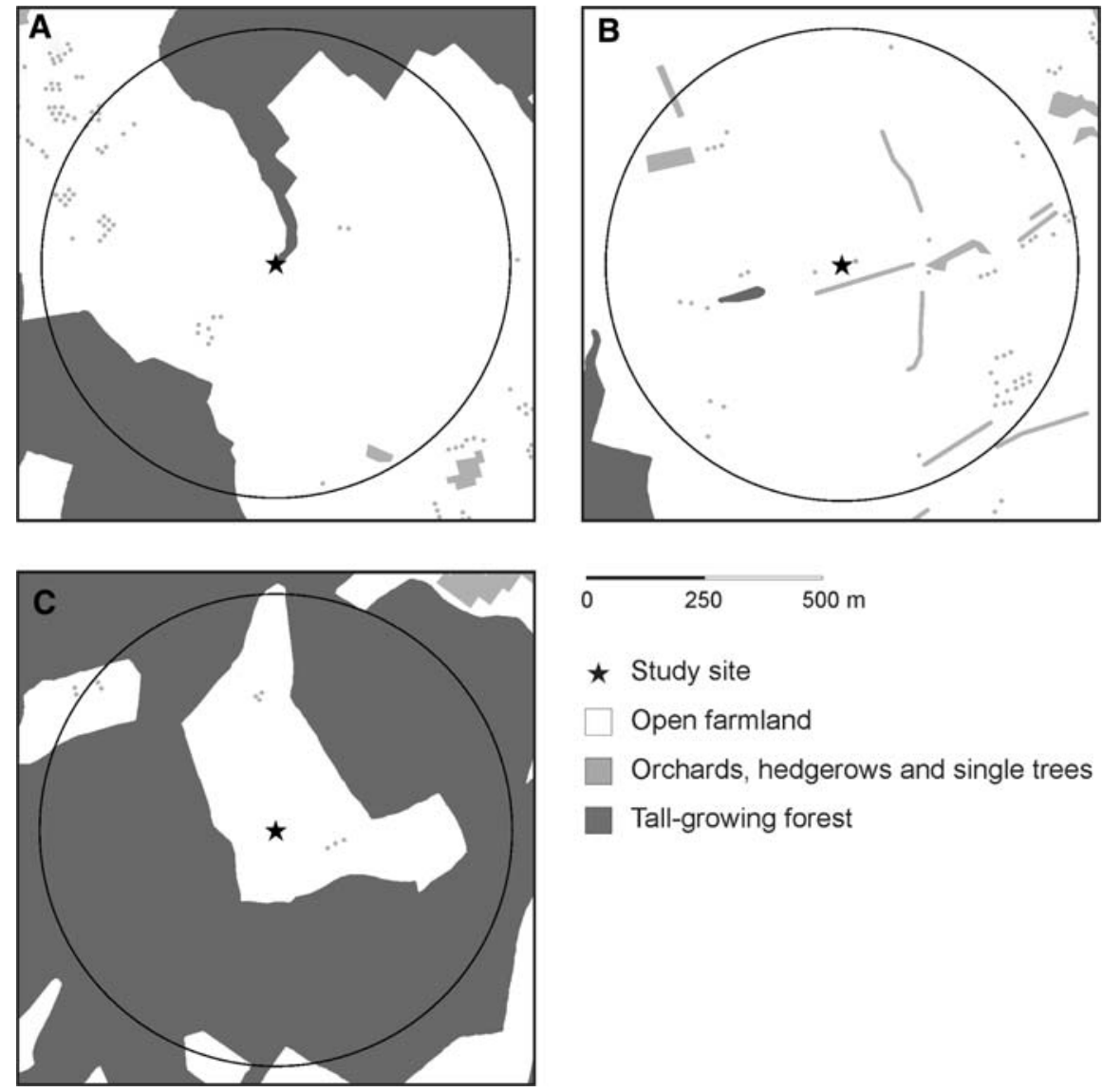

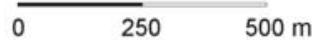

Study site

Open farmland

Orchards, hedgerows and single trees

Tall-growing forest
To determine insect scavenging, the same two types of gauze were placed at each site containing cricket (Acheta domesticus) corpses. Each gauze sheet contained ten cricket corpses that were attached to the gauze in the same way as the sunflower seeds. New corpses were placed on the cloth at intervals of 3 days and each site was visited three times (17.04.2008-23.04.2008). The number of lost and damaged cricket corpses was recorded.

\section{Statistical analyses}

Generalized linear models were used to test for effects of woody habitat cover, open semi-natural habitat cover (both log-transformed) and isolation from forest edge on pollination controlling for number of open flowers and surrounding flower cover (log-transformed). Response variables were floral visits and proportion of flowers setting seed, the former modelled following a quasi-Poisson error distribution and the latter following a Gaussian error distribution. Generalized linear mixed models were used to test for effects of woody habitat cover, open semi-natural habitat cover (both log-transformed) and isolation from forest edge on seed predation and insect scavenging. Response variables were the proportion of seeds predated and insects scavenged, and these were modelled following a binomial error distribution. As data for seed predation and insect scavenging were collected on three occasions at the same sites we included time conditional on site as random factor (Crawley 2002). Starting with the full model we used Akaike's Information Criterion for model selection (Burnham and Anderson 2002). All analyses were done with $\mathrm{R}$ version 2.7.1 (R Development Core Team 2005).

\section{Results}

At the 30 sites, 59 floral visits were observed in total (median 1, range 0-19). The main visitors were flies and bees. Floral visits of primroses tended to increase 
with the percentage of surrounding flower cover ( $t=1.8, P=0.08$ ). However, in contrast to our expectation, neither woody nor open semi-natural habitat cover nor isolation from forest influenced the floral visits of primroses $(t<1.5, P>0.16)$. The mean proportion of flowers per site setting seed was $58 \%$ (range 13-96\%). Isolation from forest significantly reduced the proportion of flowers setting seed ( $t=2.35, P=0.03$, Fig. 2a), while woody or open semi-natural habitat cover did not affect reproductive success of primroses.

In more than three-quarters (79\%) of the 180 gauze sheets with sunflower seeds, at least one of the ten seeds was preyed upon. The presence of bird droppings and rodent feeding marks indicated the presence of these larger predators. Slugs were observed feeding on seeds on both types of gauze sheets. As expected, seed predation was significantly higher in exposed (91\%) than in enclosed (67\%) gauze sheets (Table 1). In contrast to our prediction, surrounding woody or open semi-natural habitat cover had no significant effect on seed predation. Consistent with our predictions, isolated sites experienced 26\% lower seed predation rates than connected sites or sites bordering forest areas (Table 1; Fig. 2b). This pattern was stronger for enclosed than for open gauze sheets, indicating an effect of habitat isolation mostly on invertebrates (marginally significant interaction between isolation and caging, Table 1; Fig. 2b). Seed predation rates increased during the course of the study (Table 1).

One or more cricket corpses disappeared from $85 \%$ of the 180 gauze sheets. Again, bird droppings indicated the presence of larger scavengers, and slugs were the only invertebrates observed feeding on insect corpses. In accordance with our predictions, insect scavenging was significantly higher in open (98\%) than in caged (87\%) gauze sheets (Table 1; Fig. 2c). In contrast to our expectations woody or open semi-natural habitat cover had no significant impact on insect scavenging. In line with our predictions, isolated sites had $21 \%$ lower scavenging rates than sites connected to small-sized woody habitats or forest (Table 1; Fig. 2c). Congruent with the seed predation rates, the negative effect of isolation was more pronounced in enclosed than in open gauze sheets (significant interaction between isolation and caging, Table 1; Fig. 2c). Again, scavenging rates rose during the course of the study.
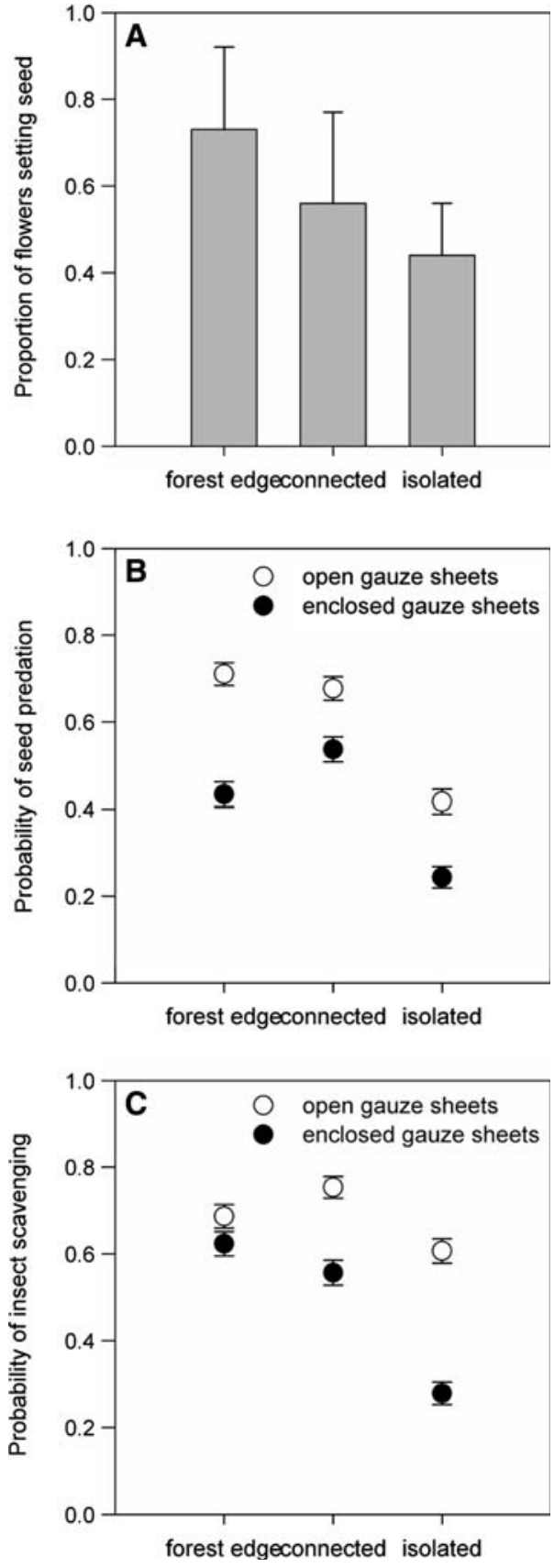

Fig. 2 Proportion of a flowers setting seed, mean predicted probability of $\mathbf{b}$ seed predation, and mean predicted probability of $\mathbf{c}$ insect scavenging predation in relation to isolation from forest (means $\pm 95 \%$ confidence intervals)

\section{Discussion}

Pollination success, seed predation and insect scavenging were negatively affected by isolation from 
Table 1 Effects of isolation from forest, caging and time on seed predation and insect scavenging

\begin{tabular}{|c|c|c|c|c|c|c|}
\hline \multirow[t]{2}{*}{ Random effects } & \multicolumn{3}{|c|}{ Seed predation } & \multicolumn{3}{|c|}{ Insect scavenging } \\
\hline & Variance & & & Variance & & \\
\hline Site & 3.80 & & & 2.79 & & \\
\hline Time & 0.36 & & & 1.37 & & \\
\hline Fixed effects & Estimate & SE & $z$ & Estimate & SE & $z$ \\
\hline Intercept & -3.42 & 1.07 & $-3.21 * *$ & 0.11 & 0.70 & $0.17 \mathrm{NS}$ \\
\hline Caging & -0.77 & 0.35 & $-2.18^{*}$ & -3.07 & 0.36 & $-8.63 * * *$ \\
\hline Isolation & 1.41 & 0.48 & $2.94 * *$ & -0.71 & 0.19 & $-2.45^{*}$ \\
\hline Time & 1.34 & 0.15 & $9.26 * * *$ & 2.10 & 0.24 & $8.79 * * *$ \\
\hline Caging* isolation & -0.31 & 0.16 & $-1.92^{\mathrm{a}}$ & 0.84 & 0.16 & $5.31 * * *$ \\
\hline
\end{tabular}

Shown are variance and standard deviation for random effects and estimate, standard error, $z$-value and significance for fixed effect from generalized linear models

${ }^{\text {a }} 0.05<P<0.1$, significant effects in italic

*** $P<0.001, * * P<0.01, * P<0.05$

forest. However, variation in woody or open seminatural habitat cover did not appear to affect the functioning of the studied ecosystem processes in the Swiss midlands during spring.

Floral visits of primroses were not significantly affected by woody habitat cover, open semi-natural habitat cover or isolation. This contrasts with the majority of studies which demonstrated a reduction of diversity and abundance of floral visitors in small and isolated habitat patches (e.g. Steffan-Dewenter and Tscharntke 1999; Kremen et al. 2002). However, a number of generalist pollinator species have been reported to frequently use the floral resources even in intensively used matrix habitat (Wilcock and Neiland 2002; Westphal et al. 2003). Further, several pollinator species are able to cross large barriers (Schulke and Waser 2001). However, our results with respect to flower visitation should be interpreted with care, because of the low numbers of observed pollinators. Remarkably, the proportion of primrose flowers setting seeds was negatively affected by isolation from forest. This is in line with studies showing that reproductive output of plants is negatively affected by habitat fragmentation but these studies also recorded reduced pollinator activity in fragmented sites (Didham et al. 1996; Steffan-Dewenter and Tscharntke 1999; Aguilar et al. 2006). Decreasing seed set with increasing isolation might be explained by the availability and isolation of outcrossing mates (Brys et al. 2004). Thus, our study suggests that even though we did not record fewer floral visitors at isolated grassland sites, reproductive success of primroses seems to be negatively affected by local isolation from forest edges.

We were able to show that both vertebrates and invertebrates contribute to predation of sunflower seeds because predation rates were higher in open gauze sheets than in enclosed gauze sheets (Donoso et al. 2003). Our study showed a strong negative effect of habitat isolation from forest edges on seed predation indicating reduced abundance of seed predators in open agricultural landscapes. Particularly, invertebrate seed predators were negatively affected by isolation as the seed predation from enclosed gauze sheets was much lower than from open gauze sheets in isolated sites. This agrees with a number of studies showing that especially invertebrate species are negatively influenced by isolation to the natural source habitat (e.g. Kruess and Tscharntke 2000; Mortimer et al. 2002; Armitage and Fong 2004; Watts and Didham 2006). For instance, a study on invertebrate colonisation of potted plants in New Zealand showed a significant decrease in total species richness and abundance of invertebrates with increasing distance from the source habitat (Watts and Didham 2006). Thus, even short distances (100 m) from forest edges can modify ecosystem functions provided by invertebrate communities. This contrasts with the much larger scales at which densities of pollinators and insect predators have been shown to 
be affected by habitat fragmentation (Thies and Tscharntke 1999; Steffan-Dewenter et al. 2002; Schmidt et al. 2008).

Similarly to the seed predation results, insect scavenging was highest from open gauze sheets. Generally, experimentally exposed invertebrate cadavers disappear very rapidly (Retana et al. 1991; Lundgren et al. 2005; Yang 2006). For instance, one study found that $97 \%$ of the experimentally exposed invertebrate baits were scavenged by ants in less than $40 \mathrm{~min}$ (Retana et al. 1991). Our observations are consistent with the literature suggesting resource limitation of scavenger populations in most ecosystems (Pimm 1982; Nisbet et al. 1997). Again, isolation from forest had a negative effect on the consumption rate of exposed insect cadavers. This agrees with results from Watts and Didham (2006) that showed that predator species richness as well as predator-prey ratio decline with increasing isolation. Again the significant interaction between caging and isolation shows a higher sensitivity of smaller scavengers to isolation.

All three studied ecosystem services appeared to rely on mobile animals from forest edges or woody habitats. Similarly, other studies have shown that semi-natural habitats in agricultural areas serve as important population sources for ecosystem service providing animals (Duelli and Obrist 2003; Kremen et al. 2004; Jauker et al. 2009). Therefore, decreasing ecosystem services at isolated sites can be related to mobility constraints of pollinators, predators and scavengers.

\section{Conclusions}

Our study suggests that the percentage of woody or open semi-natural habitat in the surrounding landscape is of minor importance for the three studied ecosystem services during spring. However, higher reproductive success, seed predation and insect scavenging rates at forest-adjoining and connected sites indicate that even small landscape elements like hedgerows and single trees can enhance the functioning of invertebrate communities in adjoining grassland. Thus, all three studied services responded quite similarly to the studied landscape gradient. The observed small-scale determination of seed predation and insect scavenging contrasts with the larger-scale determination of pollination and insect pest control found in other studies.

Acknowledgments We are grateful to the 30 farmers who allowed access to their land. We thank Dana G. Berens, Jason M. Tylianakis and two anonymous reviewers for comments on the manuscript. The study was supported by the Swiss National Science foundation under grant number 3100A0-114058 to Felix Herzog and Martin Schmidt-Entling.

\section{References}

Aguilar R, Ashworth L, Galetto L, Aizen MA (2006) Plant reproductive susceptibility to habitat fragmentation: review and synthesis through a meta-analysis. Ecol Lett 9:968-980. doi:10.1111/j.1461-0248.2006.00927.x

Armitage AR, Fong P (2004) Gastropod colonization of a created coastal wetland: potential influences of habitat suitability and dispersal ability. Restor Ecol 12:391-400. doi:10.1111/j.1061-2971.2004.00358.x

Aviron S, Nitsch H, Jeanneret P, Buholzer S, Luka H, Pfiffner L, Pozzi S, Schüpbach B, Walter T, Herzog F (2009) Ecological cross compliance promotes farmland biodiversity in Switzerland. Front Ecol Environ 7:247-252. doi:10.1890/070197

Billeter R, Liira J, Bailey D, Bugter R, Arens P, Augenstein I, Aviron S, Baudry J, Bukacek R, Burel F, Cerny M, De Blust G, De Cock R, Diekötter T, Dietz H, Dirksen J, Durka W, Frenzel M, Hamersky R, Hendrickx F, Herzog F, Klotz S, Koolstra B, Lausch A, Le Coeur D, Maelfait JP, Opdam P, Roubalova M, Schermann A, Schermann N, Schmitt T, Schweiger O, Smulders MJM, Speelmans M, Simova P, Verboom J, van Wingerden W, Zobel M, Edwards PJ (2008) Indicators for biodiversity in agricultural landscapes: a pan-European study. J Appl Ecol 45:141-150

Brys R, Jacquemyn H, Endels P, Van Rossum F, Hermy M, Triest L, De Bruyn L, De Blust G (2004) Reduced reproductive success in small populations of the selfincompatible Primula vulgaris. J Ecol 92:5-14. doi: 10.1046/j.0022-0477.2004.00840.x

Burnham KP, Anderson DR (2002) Model selection and multimodel inference: a practical information-theoretic approach, 2nd edn. Springer, New York 488 pp

Chapin FS, Zavaleta ES, Eviner VT, Naylor RL, Vitousek PM, Reynolds HL, Hooper DU, Lavorel S, Sala OE, Hobbie SE, Mack MC, Diaz S (2000) Consequences of changing biodiversity. Nature 405:234-242. doi:10.1038/35012241

Crawley MJ (2002) Statistical computing. An introduction to data analysis using S-Plus. Whiley, NewYork

Didham RK, Ghazoul J, Stork NE, Davis AJ (1996) Insects in fragmented forests: a functional approach. Trends Ecol Evol 11:255-262. doi:10.1016/0169-5347(96)20047-3

Diekötter T, Haynes KJ, Mazeffa D, Crist TO (2007) Direct and indirect effects of habitat area and matrix composition on species interactions among flower-visiting insects. Oikos 116:1588-1598. doi:10.1111/j.0030-1299.2007.15963.x

Donoso DS, Grez AA, Simonetti JA (2003) Effects of forest fragmentation on the granivory of differently sized seeds. 
Biol Conserv 115:63-70. doi:10.1016/S0006-3207(03) 00094-6

Duelli P, Obrist MK (2003) Regional biodiversity in an agricultural landscape: the contribution of seminatural habitat islands. Basic Appl Ecol 4:129-138. doi:10.1078/14391791-00140

Fahrig L (2003) Effects of habitat fragmentation on biodiversity. Annu Rev Ecol Evol Syst 34:487-515. doi: 10.1146/annurev.ecolsys.34.011802.132419

Farwig N, Bleher B, Von der Gönna S, Böhning-Gaese K (2008) Does forest fragmentation and selective logging affect seed predators and seed predation rates of Prunus africana (Rosaceae)? Biotropica 40:218-224. doi:10.1111/j.17447429.2007.00365.x

Foley JA, DeFries R, Asner GP, Barford C, Bonan G, Carpenter SR, Chapin FS, Coe MT, Daily GC, Gibbs GC, Helkowski HK, Helkowski JH, Hollowy T, Howard EA, Kucharik CJ, Monfreda C, Patz JA, Prentice IC, Ramankutty N, Synder PK (2005) Global consequences of land use. Science 309:570-574. doi:10.1126/science. 1111772

Fournier E, Loreau M (2001) Respective roles of recent hedges and forest patch remnants in the maintenance of groundbeetle (Coleoptera: Carabidae) diversity in an agricultural landscape. Landscape Ecol 16:17-32. doi:10.1023/A:1008 115516551

Griffith J, Phillips DS, Compton SG, Wright C, Incoll LD (1998) Responses of slug numbers and slug damage to crops in a silvoarable agroforestry landscape. J Appl Ecol 35:252-260. doi:10.1046/j.1365-2664.1998.00291.x

Haynes KJ, Diekötter T, Crist TO (2007) Resource complementation and the response of an insect herbivore to habitat area and fragmentation. Oecologia 153:511-520. doi:10.1007/s00442-007-0749-4

Jacquemyn H, Brys R, Hermy M (2001) Patch occupancy, population size and reproductive success of a forest herb (Primula elatior) in a fragmented landscape. Oecologia 11:413-418

Jauker F, Diekötter T, Schwarzbach F, Wolters V (2009) Pollinator dispersal in an agricultural matrix: opposing responses of wild bees and hoverflies to landscape structure and distance from main habitat. Landscape Ecol 24:547-555. doi:10.1007/s10980-009-9331-2

Kirika JM, Bleher B, Böhning-Gaese K, Chira R, Farwig N (2008) Fragmentation and local disturbance of forests reduce frugivore diversity and fruit removal in Ficus thonningii. Basic Appl Ecol 9:663-672. doi:10.1016/ j.baae.2007.07.002

Klein AM, Vaissière BE, Cane JH, Steffan-Dewenter I, Cunningham SA, Kremen C, Tscharntke T (2007) Importance of pollinators in changing landscapes for world crops. Proc R Soc B Biol Sci 274:303-313

Kotze DJ, Lawes MJ (2007) Viability of ecological processes in small Afromontane forest patches in South Africa. Aust Ecol 32:294-304. doi:10.1111/j.1442-9993.2007.01694.x

Kremen C, Williams NM, Thorp RW (2002) Crop pollination from native bees at risk from agricultural intensification. Proc Natl Acad Sci USA 99:16816-16821. doi:10.1073/ pnas.262413599

Kremen C, Williams NM, Bugg RL, Fay JP, Thorp RW (2004) The area requirements of an ecosystem service: crop pollination by native bee communities in California. Ecol Lett 7:1109-1119. doi:10.1111/j.1461-0248.2004.00662.x Kremen C, Williams NM, Aizen MA, Gemmill-Harren B, LeBuhn G, Minckley R, Packer L, Potts SG, Roulston T, Steffan-Dewenter I, Vazquez DP, Winfree R, Adams L, Crone EE, Greenlead SS, Keitt TH, Klein AM, Regetz J, Ricketts TH (2007) Pollination and other ecosystem services produced by mobile organisms: a conceptual framework for the effects of land-use change. Ecol Lett 10:299-314. doi:10.1111/j.1461-0248. 2007.01018.x

Kruess A, Tscharntke T (1994) Habitat fragmentation, species loss, and biological control. Science 264:581-1584. doi: 10.1126/science.264.5165.1581

Kruess A, Tscharntke T (2000) Species richness and parasitism in a fragmented landscape: experiments and field studies with insects on Vicia sepium. Oecologia 122:129-137. doi:10.1007/PL00008829

Larsen TH, Williams NM, Kremen C (2005) Extinction order and altered community structure rapidly disrupt ecosystem functioning. Ecol Lett 8:538-547. doi:10.1111/j.14610248.2005.00749.x

Luck GW, Daily GC, Ehrlich PR (2003) Population diversity and ecosystem services. Trends Ecol Evol 18:331-336. doi:10.1016/S0169-5347(03)00100-9

Lundgren JG, Shaw JT, Zaborski ER, Eastman CE (2005) The influence of organic transition systems on beneficial ground-dwelling arthropods and predation of insects and weed seeds. Renew Agr Food Syst 21:227-237

Matson PA, Parton WJ, Power AG, Swift MJ (1997) Agricultural intensification and ecosystem properties. Science 277:504-509. doi:10.1126/science.277.5325.504

Meek B, Loxton D, Sparks T, Pywell R, Pickett H, Nowakowski M (2002) The effect of arable field margin composition on invertebrate biodiversity. Biol Conserv 106:259-271. doi:10.1016/S0006-3207(01)00252-X

Mortimer SR, Booth RG, Harris SJ, Brown VK (2002) Effects of initial site management on the Coleoptera assemblages colonising newly established chalk grassland on ex-arable land. Biol Conserv 104:301-313. doi:10.1016/S0006-3207 (01)00195-1

Nisbet RM, Diehl S, Wilson WG, Cooper SD, Donalson DD, Kratz K (1997) Primary-productivity gradients and shortterm population dynamics in open systems. Ecol Monogr 67:535-553

Pimm SL (1982) Food webs. Chapman \& Hall, London

Retana J, Cerdà X, Espadaler X (1991) Arthropod corpses in a temperate grassland: a limited supply? Ecography 14:6367. doi:10.1111/j.1600-0587.1991.tb00634.x

R Development Core Team (2005) A language and environment for statistical computing. R Foundation for Statistical Computing, Vienna, Austria. Available at http://www. R-project.org

Robinson RA, Sutherland WJ (2002) Post-war changes in arable farming and biodiversity in Great Britain. J Appl Ecol 39:157-176. doi:10.1046/j.1365-2664.2002.00695.x

Sanderson FJ, Kloch A, Sanchanowicz K, Donald PF (2009) Predicting the effects of agricultural change on farmland bird populations in Poland. Agric Ecosyst Environ 129:37-42. doi:10.1016/j.agee.2008.07.001 
Saunders DA, Hobbs RJ, Margules CR (1991) Biological consequences of ecosystem fragmentation: a review. Conserv Biol 5:18-32. doi:10.1111/j.1523-1739.1991. tb00384.x

Schmidt MH, Thies C, Nentwig W, Tscharntke T (2008) Contrasting responses of arable spiders to the landscape matrix at different spatial scales. J Biogeogr 35:157-166

Schulke B, Waser NM (2001) Long-distance pollinator flights and pollen dispersal between populations of Delphinium nuttallianum. Oecologia 127:239-245. doi:10.1007/s0044 20000586

Steffan-Dewenter I, Tscharntke T (1999) Effects of habitat isolation on pollinator communities and seed set. Oecologia 121:432-444. doi:10.1007/s004420050949

Steffan-Dewenter I, Munzenberg U, Burger U, Thies C, Tscharntke T (2002) Scale-dependent effects of landscape context on three pollinator guilds. Ecology 83:1421-1432

Thies C, Tscharntke T (1999) Landscape structure and biological control in agroecosystems. Science 285:893-895. doi:10.1126/science.285.5429.893

Tilman D, Cassman KG, Matson PA, Naylor R, Polasky S (2002) Agricultural sustainability and intensive production practices. Nature 418:671-677. doi:10.1038/nature01014

Tivy J (1990) Agricultural ecology. Longman Scientific and Technical, UK

Tscharntke T, Klein AM, Kruess A, Steffan-Dewenter I, Thies C (2005) Landscape perspectives on agricultural intensification and biodiversity-ecosystem service management. Ecol Lett 8:857-874. doi:10.1111/j.1461-0248. 2005.00782.x
Tscharntke T, Bommarco R, Clough Y, Crist TO, Kleijn D, Rand TA, Tylianakis JM, van Nouhuys S, Vidal S (2007) Conservation biological control and enemy diversity on a landscape scale. Biol Control 43:294-309. doi:10.1016/ j.biocontrol.2007.08.006

Tylianakis JM, Didham RK, Bascompte J, Wardle DA (2008) Global change and species interactions in terrestrial ecosystems. Ecol Lett 11:1351-1363. doi:10.1111/j.14610248.2008.01250.x

Valentine DH (1948) Studies in British Primulas. II. Ecology and taxonomy of primrose and oxlip (Primula vulgaris Huds. and P. elatior Schreb.). New Phytol 47:111-130. doi:10.1111/j.1469-8137.1948.tb05095.x

Watts CH, Didham RK (2006) Influences of habitat isolation on invertebrate colonization of Sporadanthus ferrugineus in a mined peat bog. Restor Ecol 14:412-419. doi:10.1111/ j.1526-100X.2006.00149.x

Westphal C, Steffan-Dewenter I, Tscharntke T (2003) Mass flowering crops enhance pollinator densities at a landscape scale. Ecol Lett 6:961-965. doi:10.1046/j.1461-0248. 2003.00523.x

White SS, Renner KA, Menalled FD, Landis DA (2007) Feeding preferences of weed seed predators and effect on weed emergence. Weed Sci 55:606-612. doi:10.1614/ WS-06-162.1

Wilcock C, Neiland R (2002) Pollination failure in plants: why it happens and when it matters. Trends Plant Sci 7:270277. doi:10.1016/S1360-1385(02)02258-6

Yang LH (2006) Interactions between a detrital resource pulse and a detritivore community. Oecologia 147:522-532 